Table 3 Effect of DIDS and chloride absence on acid-loading rate $\left(J_{\text {load }}\right)$ following a $10 \% \mathrm{CO}_{2}$ prepulse

\begin{tabular}{lrrcc}
\hline & & & $\left.J_{\text {load }(\mu \mathrm{M}} \mathrm{s}^{-1}\right)$ & \\
& Control & DIDS & No chloride & $\begin{array}{c}\text { DIDS-sensitive } \\
\text { (HCO } \\
\text { transport) }\end{array}$ \\
- AVP & $630 \pm 22$ & $62 \pm 3$ & $51 \pm 5$ & 568 \\
+ AVP & $1,504 \pm 76$ & $119 \pm 9$ & $80 \pm 3$ & 1,385 \\
AVP dep. & $874 \pm 35$ & $57 \pm 8$ & $31 \pm 7$ & 717 \\
\% Stimulation & $140 \pm 11$ & & & 143 \\
\hline
\end{tabular}

Fluxes calculated as in Table 1, but at $\mathrm{pH}$ 7.7. $\beta_{\mathrm{HCO}_{3}^{-}}$was $114.9 \mathrm{mM}$ per $\mathrm{pH}$ unit at $\mathrm{pH}_{\mathrm{i}} 7.7$.

crucial mitogenic signal. It could be advantageous for an activated cell to maintain a steady-state $\mathrm{pH}_{\mathrm{i}}$ close to the unactivated level given the sensitivity to $\mathrm{pH}$ of nearly all cellular processes. Such a steady-state $\mathrm{pH}_{\mathrm{i}}$ is achieved when processes that acidload the cell (for example $\mathrm{Na}^{+}$-independent $\mathrm{Cl}^{-} / \mathrm{HCO}_{3}^{-}$ exchange) balance those that alkali-load it (for example, $\mathrm{Na}^{+} / \mathrm{H}^{+}$) and $\mathrm{Na}^{+}$-dependent $\mathrm{Cl}^{-} / \mathrm{HCO}_{3}^{-}$exchange). It would also be advantageous however, for the activated cell to be able to recover more rapidly from acid and alkali loads. The requirements for both a near-normal steady-state $\mathrm{pH}_{\mathrm{i}}$ and enhanced $\mathrm{pH}_{\mathrm{i}}$ regulation can only be met if increases in acid loading and acid extrusion by the growth factor are comparable. This is precisely the response of the mesangial cell to AVP: application of the growth factor causes only a small decrease in steadv-state $\mathrm{pH}_{\mathrm{i}}$, but enormous increases in the rate at which the cell recovers from both acid (Fig. 1 $a$ ) and alkali loads (Fig. 2c). This effect of AVP on $\mathrm{pH}_{\mathrm{i}}$ does not seem to be an isolated event, as we have found eight other growth factors that also produce only a small $\mathrm{pH}_{\mathrm{i}}$ decrease in the presence of $\mathrm{HCO}_{3}^{-}$(data not shown). Thus, an important physiological effect of the growth factor is to maintain a near-normal $\mathrm{pH}_{\mathrm{i}}$ while stimulating several acidbase transporters.

Received 12 December; accepted 28 December 1988

1. Schuldiner, S. \& Rozengurt, E. Proc. natn. Acad. Sci. U.S.A. 79, 7778-7782 (1982)

2. Moolenaar, W. H., Tsien, R. Y., van der Saag, P. T. \& de Laat, S. W. Nature 304, 645-648 (1983).

3. Rothenberg, P., Glaser, L., Schlesinger, P. \& Cassel, D. J. biol. Chem. 20, 12644-12653 (1983)

4. Grinstein, S., Cohen, S., Goetz, J. D., Rothstein, A. \& Gelfand, E. W. Proc. natn. Acad. Sci. U.S.A. 82, 1429-1433 (1985).

5. Pouyssegur, J., Sardet, C., Franchi, A., L'Allemain, G. \& Paris, S. Proc. natn. Acad. Sci. U.S.A. 81, 4833-4837 (1984).

6. Pouyssegur, J., Franchi, A., L'Allemain, G. L. \& Paris, S. FEBS Lett. 190, 115-119 (1985).

7. Cassel, D., Whiteley, B. Zhuang, Y. X. \& Glaser, L. J. Cell Physiol. 122, 178-186 (1985).

8. Ganz, M. B., Boyarsky, G., Boron, W. F. \& Sterzel, R. B. Am. J. Physiol. 254, F787-F794 (1988).

9. Moolenaar, W. H. J. biol. Chem. (in the press).

10. Boyarsky, G., Ganz, M. B., Sterzel, B. \& Boron, W. F. Am. J. Physiol. 255, C844-C856 (1988),

11. Boyarsky, G., Ganz, M. B., Sterzel, B. \& Boron, W. F. Am. J. Physiol 255, C857-C869 (1988).

12. Boron, W. F. \& De Weer, P. J. gen. Physiol. 67, 91-112 (1976).

13. Boron, W. F. \& Boulpaep, E. L. J. gen. Physiol. 81, 53-94 (1983)

13. Roos, A. \& Boron, W. F. Physiol. Rev. 61, 296-434 (1981).

15. Lovett, D. H., Ryan, J. L. \& Sterzel, R. B. J. Immun. 131, 2830-2836 (1983).

16. Rink, T. J., Tsien, R. Y. \& Pozzan, T. J. Cell Biol 95, 189-196 (1982)

17. Thomas, J. A., Buchsbaum, R. N., Zimniak, A. \& Racker, E. Biochemistry 81, 2210-2218 (1979)

\section{A pentapeptide as minimal antigenic determinant for MHC class I-restricted T lymphocytes}

\author{
Matthias J. Reddehase*, Jonathan B. Rothbard $\dagger$ \\ \& Ulrich H. Koszinowskił
}

* Federal Research Centre for Virus Diseases of Animals, POB 1149,
7400 Tübingen, FRG
† Laboratory of Molecular Immunology, Imperial Cancer Research
Fund, Lincoln's Inn Fields, London WC2A 3PX, UK
† Department of Virology, Institute for Microbiology,
University of Ulm, POB 4066, 7900 Ulm, FRG

Peptides that are antigenic for $\mathrm{T}$ lymphocytes are ligands for two receptors, the class I or II glycoproteins that are encoded by genes in the major histocompatibility complex, and the idiotypic $\alpha / \beta$ chain $T$-cell antigen receptor ${ }^{1-9}$. That a peptide must bind to an MHC molecule to interact with a $\mathrm{T}$-cell antigen receptor is the molecular basis of the MHC restriction of antigen-recognition by T lymphocytes ${ }^{10,11}$. In such a trimolecular interaction the aminoacid sequence of the peptide must specify the contact with both receptors: agretope residues bind to the $\mathrm{MHC}$ receptor and epitope residues bind to the $\mathrm{T}$-cell antigen receptor ${ }^{12,13}$. From a compilation of known antigenic peptides, two algorithms have been proposed to predict antigenic sites in proteins. One algorithm uses linear motifs in the sequence ${ }^{14}$, whereas the other considers peptide conformation and predicts antigenicity for amphipathic $\alpha$ helices $^{15,16}$. We report here that a systematic delimitation of an antigenic site precisely identifies a predicted pentapeptide motif as the minimal antigenic determinant presented by a class I MHC molecule and recognized by a cytolytic $T$ lymphocyte clone.

Synthetic peptides have been derived from the amino-acid sequence of pp89, an immediate-early (IE) phase regulatory protein of murine cytomegalovirus ${ }^{17-20}$. The 19 -mer $\mathrm{P}(161-179)$ contained within its 595 residues $^{18}$ is an antigenic sequence ${ }^{21}$. This sequence $\mathrm{H}_{2} \mathrm{~N}^{161}$ GRLMYDMYPHFMPTNLGPS ${ }^{179}$ -
Table 1 Delimitation of the antigenic motif for CTL clone IE1

\begin{tabular}{|c|c|c|c|c|}
\hline & \multirow[b]{2}{*}{ Peptide } & \multirow[b]{2}{*}{$\begin{array}{l}\text { Recognition } \\
\text { (competition) }\end{array}$} & \multicolumn{2}{|c|}{$\begin{array}{c}\text { Peptide concentration } \\
{[\log \mathbf{M}]}\end{array}$} \\
\hline & & & $\begin{array}{l}\text { detection } \\
\text { limit }\end{array}$ & $\begin{array}{l}\text { detection } \\
\text { saturation }\end{array}$ \\
\hline 11-mer: & MYPHFMPTNLG & + & -7 to -6 & -4 to -3 \\
\hline \multirow[t]{2}{*}{ 10-mers: } & MYPHFMPTNL & + & -9 to -8 & -7 to -6 \\
\hline & YPHFMPTNLG & + & -8 to -7 & -6 to -5 \\
\hline \multirow{2}{*}{ 9-mers: } & MYPAFMPTN & $-(-)$ & & \\
\hline & $\begin{array}{l}\text { YPHFMPTNL } \\
\text { PHFMPTNLG }\end{array}$ & $\begin{array}{c}+ \\
+(-)\end{array}$ & $\begin{array}{l}-12 \text { to }-10 \\
-4 \text { to }-3\end{array}$ & $\begin{array}{c}-9 \text { to }-7 \\
-2\end{array}$ \\
\hline \multirow[t]{2}{*}{ 8-mers: } & YPHFMPTN & $-(-)$ & & \\
\hline & PHFMPTNL & $+(-)$ & -4 to -3 & \\
\hline \multirow[t]{3}{*}{ 7-mers: } & YP $\overline{\underline{H F M P T}}$ & - & & \\
\hline & PHFMPTN & + & -8 to -7 & -4 \\
\hline & HFMPTNL & + & -5 to -4 & \\
\hline \multirow[t]{4}{*}{ 6-mers: } & YPHFMP & _- & & \\
\hline & PHFMPTN & + & -2 to -3 & \\
\hline & HFMPTN & + & -2 & \\
\hline & FMPTNL & - & & \\
\hline 5-mer: & $\overline{\mathrm{HFMPT}}$ & + & -3 & \\
\hline \multirow{2}{*}{ 4-mers: } & HFMP & - & & \\
\hline & FMPT & - & & \\
\hline
\end{tabular}

Dose-response titrations of peptides give the peptide molarities in solution required for detectable target formation (detection limit) and for optimal target formation (detection saturation). The concentration ranges are compiled from at least 3 and up to 12 independent experiments.

$\mathrm{COOH}$ (one-letter code) contains the predicted motif HFMPT ${ }^{14}$. By screening a series of related peptides that had been reduced in length from both terminals (not all shown), we found that the nonapeptide YPHFMPTNL represents the optimal antigenic peptide (Fig. 1 and Table 1 ) for the cytolytic $T$ lymphocyte (CTL) IE1 clone ${ }^{22,23}$. Even though binding of peptides to class I molecules has not yet been demonstrated directly, the selective recognition on $L / L^{d}$ cells implies that the $L^{d}$ molecule is the 
Fig. 1 Cytolytic assays demonstrating $\mathrm{L}^{\mathrm{d}}$ restricted recognition of peptides by CTL clone IE1 (a), and doseresponse titrations of peptides $(b)$. Each value in the peptide titrations represents the lysis determined from the plateau of a complete effector-totarget titration graph at a ratio of 20 , and each value of $\%$ specific lysis is the mean of four replicate determinations.

Methods.

Cytolytic

effector cells: The murine (BALB/c strain; $\mathrm{MHC}^{d}$ ) CTL line IE1.13-IL was derived from clone IE1 by recloning $^{22,23}$. Clone IE1 expresses an $\alpha / \beta(\mathrm{V} \beta 6)$ TCR/CD3 complex and
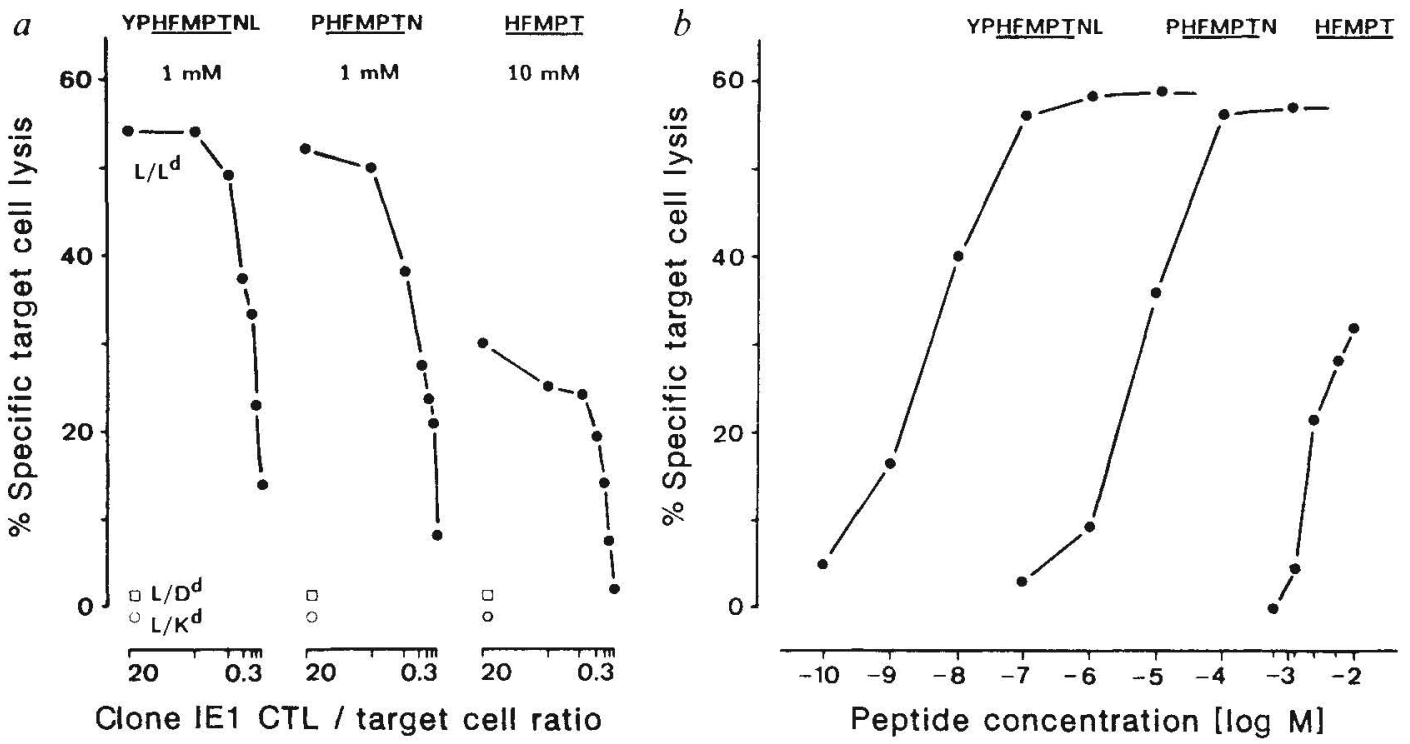
phenotype $\mathrm{CD} 4^{-} \mathrm{CD} 5 \mathrm{CD}^{+}$Thy-1 ${ }^{+}$. $\mathrm{L}$ fibroblast transfectants: $\mathrm{L} / \mathrm{L}^{\mathrm{d}}$ cells were derived from $\mathrm{L}$ cells by transfection with the $\mathrm{L}^{\mathrm{d}}$ gene, and $\mathrm{L} / \mathrm{D}^{\mathrm{d}}$ and $\mathrm{L} / \mathrm{K}^{\mathrm{d}}$ transfectants were provided by $\mathrm{M}$. Cochet and $\mathrm{J}$. P. Abastado (Institut Pasteur). Surface expression of the $\mathrm{L}^{\mathrm{d}}$, $\mathrm{D}^{\mathrm{d}}$ and $\mathrm{K}^{\mathrm{d}}$ molecules was confirmed by cytofluorography with monoclonal antibodies. Synthetic peptides: Peptides were synthesized by using the Barany-Merrifield solid-phase technique on an Applied Biosystems Peptide Synthesizer, purified preparatively and analysed as described previously ${ }^{13}$. Preparation of target cells and cytolytic assay: Target cells were labelled at $37^{\circ} \mathrm{C}$ for $1 \mathrm{~h}$ with $\mathrm{Na}_{2}\left[{ }^{51} \mathrm{Cr}\right] \mathrm{O}_{4}$. The radioactive cells were then distributed in aliquots of $10^{5}$ cells and incubated in $0.2 \mathrm{ml}$ for a further $1 \mathrm{~h}$ at $27^{\circ} \mathrm{C}$ with peptides at defined molarities $(1 \mathrm{M}$ corresponds to $10^{15}$ peptide molecules per cell) dissolved in RPMI 1640 culture medium supplemented with $2 \%$ of FCS. The highest peptide concentration tested was $10^{-2} \mathrm{M}$. This limit was imposed by the solubility of the peptides. After washing to remove excess peptide and ${ }^{51} \mathrm{Cr}$, a standard 3-h cytolytic assay was performed at $37^{\circ} \mathrm{C}$ with 1,000 target cells and graded numbers of clone IE1 CTL. Competition assays: The ability of peptides to compete with the optimal antigenic nonapeptide YPHFMPTNL was tested in two ways. Either the concentration of the antigenic peptide was kept constant at $10^{-7} \mathrm{M}$ and the competitor peptide titrated up to $10^{-4} \mathrm{M}$, or the concentration of the competitor peptide was kept constant at $10^{-4} \mathrm{M}$ and the antigenic peptide was titrated from $10^{-5}$ to $10^{-10} \mathrm{M}$. In both cases the $\mathrm{L} / \mathrm{L}^{\mathrm{d}}$ target cells were pre-incubated for $30 \mathrm{~min}$ with the competitor peptide before the antigenic peptide was added.

receptor involved in the interaction with the $T$-cell antigen receptor (TCR) of clone IE1 for the family of peptides tested (Fig. 1a). Titration of the nonapeptide YPHFMPTNL, the heptapeptide PHFMPTN, and the pentapeptide HFMPT resulted in dose-response saturation curves showing thousandfold differences in antigenic potency (Fig. $1 b$ ). The data refer to a one-hour incubation of target cells with peptide. Differences in antigenic potency are also reflected by the time needed for optimal target formation; five minutes is long enough to prepare an optimal nonapeptide target, which is in line with data for a high-affinity peptide ${ }^{24}$, whereas plateau lysis could be achieved with the pentapeptide only when the peptide pulse was prolonged to two hours or more (not shown). Because clone IE1 does not discriminate between nonapeptide and pentapeptide target once the target is formed, the limiting step is apparently the association between the peptide ligand and its $\mathrm{MHC}$ receptor on the target-cell surface. We therefore conclude that HFMPT forms the antigenic core of the peptides by comprising both the complete epitope for the TCR of clone IEI and an agretope that is adequate, but not optimal for specification of the interaction with $\mathrm{L}^{\mathrm{d}}$.

The deletion of Tyr1 (Y) from peptide YPHFMPTNL diminished and the deletion of Leu 9 (L) destroyed the antigenicity, and the resulting octapeptides PHFMPTNL and YPHFMPTN both also failed to compete with YPHFMPTNL (Table 1). According to the currently used theorem for classifying residues as T-cell contact residues or as MHC-molecule contact residues $^{12}$, Tyr 1 and Leu 9 would have been interpreted as residues contacting the MHC molecule. This conclusion, however, was proven incorrect by the findings that PHFMPTN, which lacks both residues, was $>10^{3}$-fold more antigenic than PHFMPTNL (Table 1) and could not be competed by a $10^{3}$-fold excess of YPHFMPTN (not shown), although both octapeptides include the heptapeptide sequence entirely. Results compiled in Table 1 follow a consistent pattern from the pentameric core motif up to the nonapeptide size, in that symmetric additions of residues improved the antigenicity, whereas addition of residues at either end had a negative effect.

This communication adds new aspects to the current understanding of the MHC molecule-peptide-TCR interaction. The first aspect concerns the minimal length of antigenic peptides. Until now, the shortest peptides reported as antigenic were heptapeptides presented by MHC class II molecules ${ }^{25,26}$. A recent study described a nonapeptide presented by an $\mathrm{MHC}$ class I molecule as minimal antigenic peptide of the glycoprotein of $\mathrm{LCMV}^{27}$. It should be emphasized that in our example systematic shortening from both termini was critical for the identification of the pentapeptide as the minimal antigenic peptide. Since the sequence of this pentapeptide is a predicted pentameric motif, and as most motifs are tetrameric ${ }^{14}$, recognition even of tetrapeptides may be possible.

The second aspect concerns the classification of epitope and agretope residues. For the hen egg-white lysozyme peptide (5261), Allen et al. ${ }^{12}$ defined residues as MHC-antigen contact residues when a substitution led to the loss of both antigenicity and the ability to compete with the unmodified antigenic peptide. With this approach and proposing a helical conformation, agretope residues were segregated from epitope residues. From a set of overlapping peptides, Sette t $_{\text {al }}{ }^{28}$ predicted a heptameric core in a planar conformation for the ovalbumin peptide (323339). In contrast to these examples, we have positively identified the motif HFMPT as an antigenic core in pp89 peptides by demonstrating a direct antigenicity of the pentapeptide HFMPT. The important implication is that residues whose deletion causes loss of both antigenic potency and competitive ability are not necessarily agretope residues in the classical sense of $\mathrm{MHC}$ receptor binding sites. We propose that residues flanking an antigenic core motif can affect the antigenic potency positively 
or negatively by their influence on peptide conformation.

We thank Drs U. Weber and H. Kalbacher of the Physiologisch-chemisches Institut der Universität Tübingen for preparation of some of the peptides, and Dr Margarita Del Val for critical reading of the manuscript. The technical assistance of Irene Huber and the secretarial help of Sabine Grau is gratefully acknowledged. This work was supported by the Deutsche Forschungsgemeinschaft.

Received 23 September 1988; accepted 3 January 1989

1. Thomas, D. W., Hsieh, K.-H., Schauster, J. L. \& Wilner, G. D. J. exp. Med. 153, 583-594 (1981)

2. Shimonkevitz, R., Kappler, J., Marrack, P. \& Grey, H. J. exp. Med. 158, 303-316 (1983).

3. Babbitt, B., Allen, P., Matsueda, G., Haber, E. \& Unanue, E. Nature 317, 359-361 (1985)

4. Shastri, N., Oki, A., Miller, A. \& Sercarz, E. E. J. exp. Med. 162, 332-345 (1985)

5. Townsend, A. et al. Cell 44, 959-968 (1986).

6. Bjorkman, P. J. et al. Nature 329, 506-518 (1987).

. Buus, S., Sette, A., Colon, S., Miles, C. \& Grey, H. Science 235, 1353-1358 (1987).

8. Marrack, P. \& Kappler, J. Science 238, 1073-1079 (1987).

9. Davis, M. M. \& Bjorkman, P. J. Nature 334, 395-402 (1988)

10. Zinkernagel, R. M. \& Doherty, P. C. Adv. Immun. 27, 51-177 (1979)

11. Schwartz, R. H. A. Rev. Immun. 3, 237-262 (1985)

12. Allen, P. M. et al. Nature 327, 713-715 (1987).

13. Rothbard, J. B. et al. Cell 52, 515-523 (1988).

14. Rothbard, J. B. \& Taylor, W. R. EMBO J. 7, 93-100 (1988)

15. DeLisi, C. \& Berzofsky, J. Proc. natn. Acad. Sci. U.S.A. 82, 7048-7052 (1985).

16. Margalit, H. et al. J. Immun. 138, 2213-2229 (1987).

17. Reddehase, M J \& Koszinowski, U H Nature 312, 369-371 (1984)

18. Keil, G. M., Ebeling-Keil, A. \& Koszinowski, U. H. J. Virol. 61, 1901-1908 (1987).

19. Koszinowski, U. H., Keil, G. M., Schwarz, H., Schickedanz, J. \& Reddehase, M. J. J. exp. Med. 166, 289-294 (1987).

20. Volkmer, H., Bertholet, C., Jonjic, S., Wittek, R. \& Koszinowski, U. H. J. exp. Med. 166, 668-677 (1987)

21. Del Val, M. et al, J. Virol. 62, 3965-3972 (1988)

22. Reddehase, M. J., Bühring, H.J. \& Koszinowski, U. H. J. Virol. 57, 408-412 (1986)

22. Reddehase, M. J., Bühring, H.-J. \& Koszinowski, U. H. J. Viro

24. Bodmer, H. C., Pemberton, R. M., Rothbard, J. B. \& Askonas, B. A. Cell 52, 253-258 (1988).

25. Schwartz, R. H., Fox, B. S., Fraga, E., Chen, C. \& Singh, B. J. Immun. 135, 2598-2608 (1985).

26. Good, M. F. et al. J. Immun. 140, 1645-1650 (1988).

27. Oldstone, M. B. A., Whitton, J. L., Lewicki, H. \& Tishon, A. J. exp. Med. 168, 559-570 (1988). 28. Sette, A et al Nature 328, 395-399 (1987).

Class I cross-restricted $\mathrm{T}$ cells reveal low responder allele due to processing of viral antigen

\author{
Helen C. Bodmer, Frances M. Gotch \\ \& Andrew J. McMichael
}

Institute for Molecular Medicine, John Radcliffe Hospital, Oxford OX3 9DU, UK

Cytotoxic T lymphocytes (CTL) recognize protein antigens which have been processed by the target cell and then presented in association with the relevant class I molecule of the major histocompatibility complex (MHC) ${ }^{1}$. Short synthetic peptides, which are able to associate directly with target cells ${ }^{1}$, may substitute for these processed fragments in stimulating antigen-specific CTL responses. Using this approach, a dominant HLA-A2-restricted epitope has previously been mapped to residues 58-68 of influenza A virus matrix protein ${ }^{2}$. Here we report HLA-A2-restricted CTL which are also able to recognize this short synthetic peptide in association with HLA-Aw69, but which fail to recognize HLAAw69 expressing cells infected with influenza A virus. Furthermore, individuals possessing HLA-Aw69 who respond to influenza A virus, do not respond to M58-68. These results imply that the low response to this epitope on infection of HLA-Aw69 individuals with influenza $A$ is due to failure of the naturally processed product of matrix protein to associate with Aw69.

Individuals who express the common HLA-A2 variant, HLAA2.1 (HLA-A*0202 as defined in ref. 3), and who can mount a cytotoxic response to influenza infected target cells, following in vitro stimulation with virus have been shown, in all cases tested to date, to possess CTL that specifically recognize synthetic peptides representing residues $56-68$ of the matrix protein $^{4}$. Individuals who have other variants of A2, or the closely
$1 \mathrm{~A} 10$

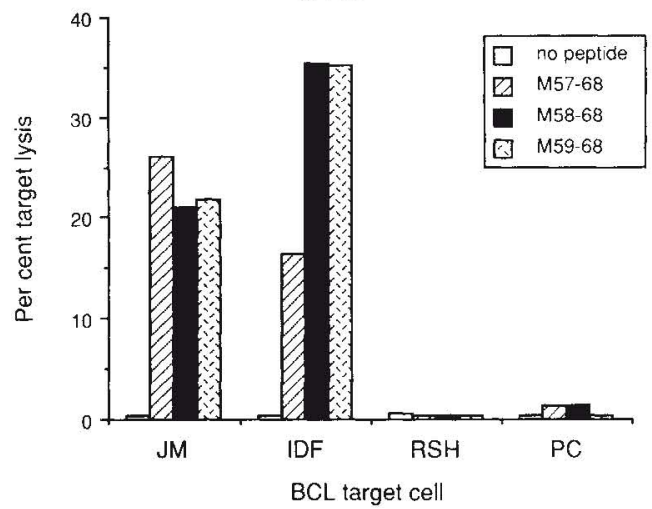

Fig. 1 CTL are cross-restricted, recognizing peptide on both autologous and Aw69-expressing target cells. Recognition by CTL clone $1 \mathrm{~A} 10$ from the donor JM (A2, 2; B15, 51; DR4, 4) of peptides M57-58, M58-68, and M59-68 of influenza matrix protein on autologous BCL target cells (JM), three HLA-mismatched BCL, IDF (A26, w69; B18, 38; DR11, 11), RSH (A68, 68; B42, 42; DR3, 3) and PC (A3, 24; B37,62; DR6,6). $K / T=1.5$, peptides present throughout assay $10 \mu \mathrm{M}$.

Methods. CTL clone 1A10 was derived from a parent line from the donor, JM. Peripheral blood lymphocytes were separated from whole blood, stimulated initially with $\mathrm{A} / \mathrm{X} 31$ virus (grown and stored as previously described ${ }^{18}$ ) and maintained in culture by repeated stimulations with peptide $\mathbf{M 5 7 - 6 8}$, as previously described $^{4}$. CTL were cloned by selection of CD8 positive cells (labelled with B941 antibody from Dr C. Mawas, and fluoresceinlabelled anti-mouse immunoglobulin) using an Ortho Cytofluorograf cell sorter, into 96-well plates containing $10^{4}$ irradiated BCL (pretreated with $50 \mu \mathrm{M} \mathrm{M} 57-68$ ) and IL-2 $10 \mathrm{U} \mathrm{ml}^{-1}$ (Cetus Corp.) in RPMI containing $10 \%$ fetal calf serum. Monoclonality was indicated by the presence of a single $\beta$-chain gene rearrangement on Southern blotting (data not shown). Cytotoxic activity was assessed by incubating EBV-transformed lymphoblastoid cells (BCL), labelled with ${ }^{51} \mathrm{Cr}$, with CTL and diluted peptide (where appropriate) for $4 \mathrm{~h}$ in round-bottomed 96 -well plates. Per cent target lysis was calculated from the formula $(E-M / D-M) \times 100$ where $E=$ experimental ${ }^{51} \mathrm{Cr}$ release, $M=$ release in presence of culture medium (always $<18 \%$ ) and $D=$ release by $5 \%$ Triton

$\mathrm{X}-100$. For details of the peptides see legend to Fig. 3.

related allele HLA-Aw69, which differs by six amino acids from A2*0202 (listed in Table 1$)^{5}$, did not respond to this region of matrix protein 4 .

We made several CTL lines and clones from a single HLA-A2 expressing individual, JM, some of which were able to recognize matrix peptide 56-68 in association with HLA-Aw69 as well as A2, although they were otherwise HLA-restricted (Fig. 2). CTL clone $1 \mathrm{~A} 10$ was able to recognize the short synthetic peptides M57-68, M58-68 and M59-68 in association with both the autologous (JM) HLA-A2-expressing EBV-transformed B lymphoblastoid cell line (BCL), and a BCL expressing Aw69 which did not share any HLA alleles with JM (Fig. 1), but did not recognize two other HLA mismatched $\mathrm{BCL}$ in the presence of these peptides.

Although these matrix-specific A2-restricted CTL were able to recognize Aw69-expressing target cells in the presence of synthetic peptide, a discrepancy between recognition of $\mathrm{A} 2$ and Aw69 BCL was seen following A/X31 virus infection of the target cells (Fig. 2). Both autologous and A2-matched BCL were recognized following pretreatment with the peptide, or infection with influenza virus (Fig. $2 a, e$ ). In contrast Aw69-expressing $\mathrm{BCL}$ were very poorly recognized following virus infection, although they were well recognized after peptide treatment (Fig. $2 b, c, f)$. In addition, virus-specific polyclonal CTL from an Aw69-expressing donor were unable to recognize the synthetic peptide M58-68 (Fig. $2 d$ ). Even with repeated stimulation of these latter CTL with M58-68 in vitro, we were unable to obtain a response from either of two Aw69-expressing (HLA identical) 